\title{
Investigating the effect of corporate governance on risk of private banks and insurance firms
}

\author{
Mehdi Taghavi $^{\mathrm{a}}$ and Mohammad Masoudi Moghadam ${ }^{\mathrm{b}}$
}

\begin{abstract}
${ }^{a}$ Professor, Department of Management, School of Management and Human Sciences, Tehran North Branch, Islamic Azad University (IAU), Tehran, Iran

${ }^{b}$ M.Sc. Student, Department of Accounting, School of Management and Human Sciences, Tehran North Branch, Islamic Azad University (IAU), Tehran, Iran

C H R O N I C L E

Article history:

Received Feb 28, 2013

Received in revised format

19 September 2013

Accepted 23 October 2013

Available online

December 42013

Keywords:

Risk taking

\section{A B S T R A C T}

This paper presents an empirical investigation to study the effects of corporate governance on risk taking of private insurance firms and banks in Iran. The proposed study of this paper considers the financial information of 13 banks and 19 private insurance firms over the period 2006-2011 in Iran. The study investigates the effects of five variables including size, CEO duality task, composition of the board of directors, ownership concentration and having an internal auditing system on risk taking of private banks and insurance firms in Iran. Using some panel data and regression analysis, the study confirms the positive effect of the ownership concentration as well as negative impact of non-bound board members on risk taking.
\end{abstract}

Private banks

Insurance firms
(C) 2014 Growing Science Ltd. All rights reserved.

\section{Introduction}

For years, there have been tremendous efforts to detect various factors influencing insurance firms (García-Marco \& Robles-Fernández, 2008; Matthews, 2007). Rahman et al. (2012) provided some evidence on the relationship between ownership structure and bank risk taking, and the impacts of capital regulation on the association on Malaysian commercial banks over the periods 1995-2008. They reported that ownership structure of Malaysian banks exerts positive influences on the banking institutions; indicating that the existence of large shareholders in Malaysian banks reduces bank risk taking and increases bank stability. They also reported that capital regulation plays an essential role in impacting ownership on bank risk taking. However, higher capital regulation had unintended impacts whereby banks could response to the regulation by increasing their risk taking. The findings thus, implied that agency hypothesis associated with expropriation of banks creditors' interest by large shareholders and the role of high capital regulation in reducing bank risk taking could not be used for Malaysian banks.

* Corresponding author. Tel: +98-912-2995919

E-mail addresses: mohamadkhodaei@yahoo.com (M. Taghavi) 
Adams and Ferreira (2007) analyzed the consequences of the board's dual role as advisor as well as monitoring management and reported that the CEO could face a trade-off in disclosing information to the board whenever he disclosed his information. Adams and Mehran (2003, 2005), in other work, investigated the corporate performance, board structure and its determinants in the banking industry. Andres and Vallelado (2008) applied a sample of large international commercial banks to examine hypotheses on the dual role of boards of directors. They used a two step system estimator to solve the well-known endogeneity problem in corporate governance literature, and showed the empirical and theoretical superiority of system estimator over OLS (Byrd \& Hickman, 1992; Bhagat \& Black, 2001) and within estimators. They detected an inverted U-shaped relation between bank performance and board size, and between the proportion of non-executive directors and performance. They explained that bank board composition and size were associated with directors' ability to monitor and to advise management. Coles et al. (2008) reexamined the relationship between firm value and board structure and reported that complex firms, which have bigger advising requirements than simple firms, keep larger boards with more outside directors. The relationship between Tobin's Q and board size was Ushaped, which, at face value, implied that either very small or very large boards could be optimal. Nevertheless, this arises from differences between complex and simple firms and Tobin's Q could increase (decrease) in board size for complex (simple) business units. Boards of directors and corporate governance continue to absorb the attention of practitioners and scholars alike (Megginson et al., 1994; Davis et al, 1997; Dalton \& Dalton, 2005; Jensen \& Meckling, 1976).

Calomiris and Mason (2003) presented a comprehensive review on fundamentals, panics, and bank distress during the depression. Eling and Marek (2011) presented a corporate governance and risk taking by looking into some evidence from European insurance markets. Franks and Mayer (2001) investigated on ownership and control of German corporations. Hermalin and Weisbach (1991, 2001) investigated the effects of board composition and direct incentives on firm performance. John and Senbet (1998) also performed an investigation on corporate governance and board effectiveness. Johnson et al. (2000) did a comprehensive survey on corporate governance in the Asian financial crisis. They reported that in countries with weak corporate governance, worse economic prospects result in more expropriation by managers and thus a larger fall in asset prices. Klein et al. (2005) studied corporate governance, family ownership and firm value in the context of Canadian corporations. Lipton and Lorsch (1992) presented a modest proposal for improved corporate governance. They presented a proposal for improved corporate governance, which could be applied voluntarily by business corporations and their boards, without relying on changes in laws, regulations, court decisions, or shareholder behavior.

\section{The proposed study}

In this paper, we present a regression model to consider the relationship between risk and some variables including size of firm, size of board of directors as follows,

$R T=\alpha+\beta_{1} B R D S Z E+\beta_{2} O U T D I R+\beta_{3} O W N C O N+\beta_{4} D U A L+\beta_{5} I N T A U D+\beta_{6} S I Z E+\beta_{7} L E V+\varepsilon$,

where BRDSZE represents the size of board of directors, OUTDIR states the ratio of non-bound board members to total board of directors and $O W N C O N$ represents ownership concentration, which represents the portion of the shareholders who own at least $5 \%$ of shares. In addition, DUAL is a dummy variable, which is one if the CEO is the chairman or vice chairman of the board and zero, otherwise, INTAUD is equal to one if the unit has independent auditor, and zero, otherwise. SIZE represents the size of the firm, which is calculated by taking a natural logarithm of the total assets and $L E V$ represents the leverage and it is the last independent variable, which is calculated as Leverage= debt/asset. The dependent variable, risk taking $(R T)$, is calculated by Z-SCORE as follows,

$\mathrm{Z}=(\mathrm{ROA}+\mathrm{CAP}) / \sigma_{\mathrm{ROA}}$ 
where $R O A$ states return on assets, which is calculated as the ratio of net profit divided by total assets, $C A P$ is the ratio of total equities to total assets and finally, $\sigma_{\mathrm{ROA}}$ is the standard deviation of ROA. The proposed study of this paper considers the following main hypothesis,

Main hypothesis: Corporate governance influences on risk taking of private insurance firms and banks.

The proposed study considers the following sub-hypotheses,

1. Size of firms influences on risk taking of private insurance firms and banks.

2. CEO duality task influences on risk taking of private insurance firms and banks.

3. Composition of the board of directors influences on risk taking of private insurance firms and banks.

4. Ownership concentration influences on risk taking of private insurance firms and banks.

5. Having internal auditing system influences on risk taking of private insurance firms and banks.

The proposed study of this paper considers the financial information of 13 banks and 19 private insurance firms over the period 2006-2011 in Iran. In summary, there were 152 data with 40 missing data. Table 1 demonstrates the summary of some basic statistics associated with the proposed study of this paper.

Table 1

The summary of some basic statistics

\begin{tabular}{|c|c|c|c|c|c|c|c|c|}
\hline \multirow{2}{*}{ Variable } & \multirow{2}{*}{ Num. } & \multirow{2}{*}{ Mean } & \multirow{2}{*}{ Standard deviation } & \multirow{2}{*}{ Variance } & \multirow{2}{*}{ Skewness } & \multirow{2}{*}{ Kurtosis } & \multicolumn{2}{|c|}{ Deviation } \\
\hline & & & & & & & Skewness & Kurtosis \\
\hline Risk taking & 152 & 12.48 & 9.249 & 85.538 & 2.393 & 8.442 & 12.162 & 21.587 \\
\hline$B R D S Z E$ & 152 & 5.434 & 1.403 & 1.969 & 1.594 & 4.632 & 8.1 & 11.844 \\
\hline OUTDIR & 152 & 0.675 & 0.211 & 0.045 & -0.87 & 0.006 & -4.421 & 0.014 \\
\hline$O W N C O N$ & 152 & 60.765 & 27.086 & 733.655 & -0.3 & -1.064 & -1.525 & -2.722 \\
\hline Lev & 152 & 0.738 & 0.204 & 0.042 & -1.064 & 0.342 & -5.409 & 0.876 \\
\hline Size & 152 & 15.733 & 3.299 & 10.882 & 1.819 & 6.658 & 9.246 & 17.026 \\
\hline
\end{tabular}

In our survey, $28.3 \%$ of the CEO had more than one responsibility and the rest of $71.7 \%$ hold more than one position. In addition, $59.2 \%$ of the firms had independent auditors while $40.8 \%$ of them did not have independent internal auditor. Next, we need to make sure about the normality of data, choosing between panel data as well as fixed or random effect. Table 2 shows details of our survey on some related statistics. The results of Table 2 indicate that data are not normally distributed. Table 3 also shows details of our survey to detect whether we should choose random effect or fixed effect.

Table 2

The summary of Kolmogorov-Smirnov, Shapiro-Wilk, Jarque- bera

\begin{tabular}{cccccccc}
\hline \multirow{2}{*}{ Variable } & \multirow{2}{*}{ Number } & \multicolumn{2}{c}{ Kolmogorov-Smirnov } & \multicolumn{2}{c}{ Shapiro-Wilk } & \multicolumn{2}{c}{ Jarque- bera } \\
\cline { 2 - 7 } & & Statistics & Sig. & Statistics & Sig. & Statistics & Sig. \\
\hline Risk taking & 152 & 0.352 & 0 & 0.748 & 0 & 188.0194 & 0 \\
BRDSZE & 152 & 0.19 & 0 & 0.906 & 0 & 18.80204 & 0.000083 \\
OUTDIR & 152 & 0.128 & 0 & 0.94 & 0 & 9.471653 & 0.008775 \\
OWNCON & 152 & 0.125 & 0 & 0.883 & 0 & 28.66623 & 0.000001 \\
Lev & 152 & 0.101 & 0.001 & 0.865 & 0 & 341.7748 & 0 \\
Size & 152 & 0.177 & 0 & 0.789 & 0 & 531.8408 & 0 \\
\hline
\end{tabular}

Based on the results of Table 3, we need to choose random effect along with panel data. Next, we need to make sure there is a linear relationship among independent variables and there is no autocorrelation between residuals. Table 4 shows details of our Durbin-Watson and F-value tests. 
Table 3

The results of Chow and Huasman tests

\begin{tabular}{cccccccc}
\hline \multirow{2}{*}{ Model } & \multirow{2}{*}{ Aim } & \multicolumn{3}{c}{ Chow test } & \multicolumn{3}{c}{ Hausman test } \\
\cline { 2 - 7 } & & F Statistics & Sig. & Result & Chi-Square & Sig. & Result \\
\hline \multirow{2}{*}{1} & Pooled & 1.437002 & 0.2146 & Equal intercept & - & - & - \\
& Panel & 14.57773 & 0 & Not equal slope & 0 & 1 & Random effect \\
\hline \multirow{2}{*}{2} & Pooled & 1.45163 & 0.2097 & Equal intercept & - & - & - \\
& Panel & 24.726634 & 0 & Not equal slope & 0 & 1 & Random effect \\
\hline
\end{tabular}

Table 4

The summary of Durbin-Watson and F-value

\begin{tabular}{ccccccc}
\hline \multirow{2}{*}{ Model } & \multicolumn{2}{c}{ Linear relationship } & \multicolumn{2}{c}{ Durbin-Watson } & \multicolumn{2}{c}{ Residuals } \\
\cline { 2 - 6 } & F-value & Sig. & D-W & Bange & $2.5-1.5$ & 212.8978 \\
First & 5.848351 & 0.000059 & 1.512872 & $2.5-1.5$ & 207.7939 & 0.000 \\
Second & 16.37016 & 0 & 1.759467 & 000 \\
\hline
\end{tabular}

The results of Table 4 show that Durbin-Watson values are within acceptable limits and F-value as well as J_B values are statistically significant. Finally, the implementation of Pearson correlation did not indicate a strong correlation among independent variables. Therefore, we can examine the hypotheses based on the results of the regression models.

\section{The results}

In this section, we present details of our findings on testing various hypotheses of the survey.

\subsection{The first model}

The first model of this survey considers the effects of independent variables on risk taking and the results are as follows,

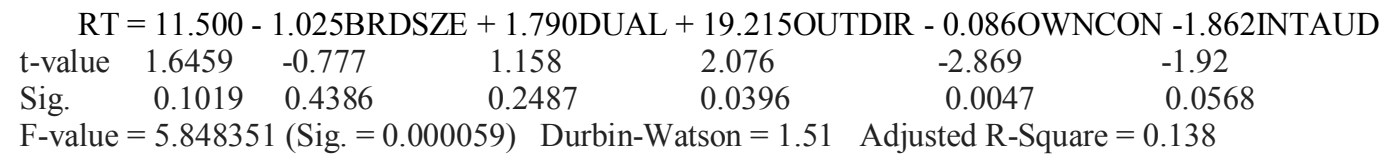

Based on the results of regression analysis, we can state that F-value is statistically significance and Durbin-Watson is equal to 1.51 , which are within desirable values. The results of regression analysis indicate that the coefficients of three variables of BRDSZE, DUAL and INTAUD are not meaningful when the level of significance is five percent. However, the coefficients of OUTDIR and OWNCON are statistically meaningful when the level of significance is five percent. In other words, only two variables have important effects on risk taking, namely, the ownership concentration as well as nonbound board members. In other words, when the number of non-bound board members increases, we may expect more risk and as the major shareholder increases the risk decreases. Therefore, the third and fourth sub-hypotheses of the survey have been confirmed but the other sub-hypotheses are not confirmed.

\subsection{The second model}

The second model of this survey considers the effects of independent variables in the presence of control variables on risk taking and the results are as follows,

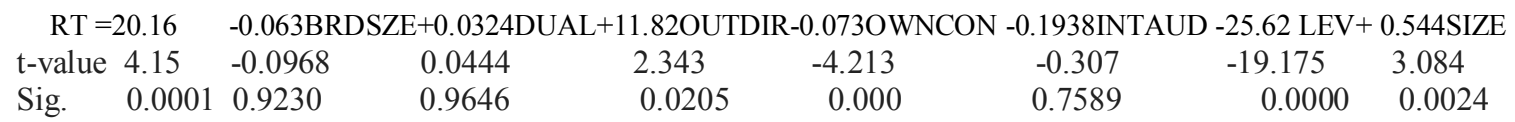

F-value $=16.37($ Sig. $=0.000000) \quad$ Durbin-Watson $=1.759467 \quad$ Adjusted R-Square $=0.416$ 
Based on the results of regression analysis, we can observe that F-value is statistically significance and Durbin-Watson is equal to 1.51, which are within desirable values. The results of regression analysis indicate that the coefficients of three variables of BRDSZE, DUAL and INTAUD are not meaningful when the level of significance is five percent. However, the coefficients of OUTDIR and OWNCON and two control variables of LEV and SIZE are statistically meaningful when the level of significance is five percent. In other words, only two independent variables have important effects on risk taking, namely, the ownership concentration as well as non-bound board members. In other words, when the number of non-bound board members increases, we may expect more risk and as the major shareholder increases the risk decreases. Therefore, the third and fourth sub-hypotheses of the survey have been confirmed but the other sub-hypotheses are not confirmed in the presence of two control variables.

\section{Conclusion}

In this paper, we have presented an empirical investigation to study the effects of corporate governance on risk taking of some private banks and insurance firms. The proposed study of this paper has gathered the necessary information from 13 banks and 19 private insurance firms over the period 2006-2011 in Iran. Using some statistical tests, the study has determined that the ownership concentration as well as non-bound board members could influence risk taking in banking and insurance industry. Table 5 shows the summary of testing various hypotheses,

Table 5

The summary of testing the effects of various factors on risk taking

\begin{tabular}{llll}
\hline Hypothesis & Independent variable & Dependent variable & Result \\
\hline First & Size of firms & Risk taking & Not confirmed \\
Second & CEO duality task & Risk taking & Not confirmed \\
Third & Composition of the board of directors & Risk taking & Confirmed \\
Forth & Ownership concentration & Risk taking & Confirmed \\
Fifth & Having internal auditing system & Risk taking & Not confirmed \\
\hline
\end{tabular}

\section{Acknowledgement}

The authors would like to thank the anonymous referees for constructive comments on earlier version of this paper.

\section{References}

Adams, R. B., \& Ferreira, D. (2007). A theory of friendly boards. The Journal of Finance, 62(1), 217250.

Adams, R., \& Mehran, H. (2003). Is corporate governance different for bank holding companies?. Available at SSRN 387561.

Adams, R. B., \& Mehran, H. (2005, August). Corporate performance, board structure and its determinants in the banking industry. In EFA 2005 Moscow meetings.

Andres, P. D., \& Vallelado, E. (2008). Corporate governance in banking: The role of the board of directors. Journal of Banking \& Finance, 32(12), 2570-2580.

Bhagat, S., \& Black, B. (2001). Non-Correlation between Board Independence and Long-Term Firm Performance. Journal of Corporation Law, 27, 231.

Byrd, J. W., \& Hickman, K. A. (1992). Do outside directors monitor managers?: Evidence from tender offer bids. Journal of Financial Economics, 32(2), 195-221.

Calomiris, C. W., \& Mason, J. R. (2003). Fundamentals, panics, and bank distress during the depression. American Economic Review, 93(5), 1615-1647.

García-Marco, T., \& Robles-Fernández, M. D. (2008). Risk-taking behaviour and ownership in the banking industry: The Spanish evidence. Journal of Economics and Business, 60(4), 332-354. 
Coles, J. L., Daniel, N. D., \& Naveen, L. (2008). Boards: Does one size fit all?. Journal of Financial Economics, 87(2), 329-356.

Rahman, N. A. A., Ahmad, N. H., \& Abdullah, N. A. H. (2012). Ownership Structure, Capital Regulation and Bank Risk Taking. Journal of Business and Economics, 176.

Dalton, C. M., \& Dalton, D. R. (2005). Boards of directors: Utilizing empirical evidence in developing practical prescriptions. British Journal of Management,16(s1), S91-S97.

Davis, J. H., Schoorman, F. D., \& Donaldson, L. (1997). Toward a stewardship theory of management. Academy of Management review, 22(1), 20-47.

Eling, M., \& Marek, S. (2011). Corporate governance and risk taking: evidence from European insurance markets. Journal of Risk and Insurance, 78(3), 519-550.

Franks, J., \& Mayer, C. (2001). Ownership and control of German corporations. Review of Financial Studies, 14(4), 943-977.

Hermalin, B. E., \& Weisbach, M. S. (1991). The effects of board composition and direct incentives on firm performance. Financial management, 20(4), 101-112.

Hermalin, B. E., \& Weisbach, M. S. (2001). Boards of directors as an endogenously determined institution: A survey of the economic literature (No. w8161). National Bureau of Economic Research.

Jensen, M. C., \& Meckling, W. H. (1976). Theory of the firm: Managerial behavior, agency costs and ownership structure. Journal of financial economics, 3(4), 305-360.

John, K., \& Senbet, L. W. (1998). Corporate governance and board effectiveness. Journal of Banking \& Finance, 22(4), 371-403.

Johnson, S., Boone, P., Breach, A., \& Friedman, E. (2000). Corporate governance in the Asian financial crisis. Journal of financial Economics, 58(1), 141-186.

Klein, P., Shapiro, D., \& Young, J. (2005). Corporate governance, family ownership and firm value: the Canadian evidence. Corporate Governance: An International Review, 13(6), 769-784.

Lipton, M., \& Lorsch, J. W. (1992). A modest proposal for improved corporate governance. The Business Lawyer, 59-77.

Matthews, W. A. (2007). The residual control roles of cooperative board of directors: a preliminary comparative analysis (Doctoral dissertation, University of Missouri--Columbia).

Megginson, W. L., Nash, R. C., \& Randenborgh, M. (1994). The financial and operating performance of newly privatized firms: An international empirical analysis. The Journal of Finance, 49(2), 403452. 